\title{
Risk society and the politics of food safety problems in China
}

\author{
Guanghua Han and Yida Zhai* (D) \\ Shanghai Jiao Tong University, Shanghai, China \\ ${ }^{*}$ Corresponding author. E-mail: yidazhai@hotmail.com
}

(Received 5 November 2020; revised 9 March 2021; accepted 26 August 2021; first published online 4 January 2022)

\begin{abstract}
In China, the public has gradually shifted their focus from GDP growth to quality-of-life issues, which imposes new challenges for the government. The food safety problem, as a salient issue, is one such example. This article analyzes how food safety problems affect ordinary Chinese people's trust in the government and their attribution of governmental responsibility using nationally representative survey data. As food safety risks are unequally distributed in China, the political impact of food safety problems varies among people of different socioeconomic statuses. The results show that food safety problems weaken the public's trust in both the central and local governments, but this negative effect is attenuated among people with a low level of education. Moreover, the Chinese public tends to attribute major responsibility to the central government rather than local governments when perceiving the severity of food safety problems, and this tendency becomes stronger for the low-income population. The results deepen the understanding of the local-central political trust patterns and the political implications of food safety problems in China.
\end{abstract}

Key words: Attribution of responsibility; food safety; hierarchical trust; inequality; political trust; risk society

\section{Introduction}

China's political system has remained resilient and many researchers contend that the legitimacy of the Chinese Communist Party's (CCP) rule lies in its satisfactory economic performance (Nathan, 2003; Laliberté and Lanteigne, 2008; Tang, 2018). However, with economic development, the public in China is not merely satisfied with the basic economic securities, but has a massive demand for better government administration in quality-of-life issues ranging from air/water pollution to the food safety problems that threaten ordinary people's health and lives (Tam and Yang, 2005; Rigg, 2007; Ross, 2012). Citizens' heightened demand from governments validates the values change and critical citizenry theories (Inglehart, 1990; Norris, 1999; Inglehart and Welzel, 2010). Hence, government administration in China is facing various new challenges to which governments have to respond. The public expects the government to perform better in dealing with these quality-of-life issues.

The food safety problem is one such prominent issue. There have been a number of food safety problems disclosed over the past two decades including poisonous ham, contaminated baby formula, and degraded cooking oil (MacLeod, 2012; Si et al., 2018). These incidents have resulted in widespread concerns and discontent among the Chinese public (Gong and Jackson, 2012; Yan, 2012; Yang, 2013). The 2015 Pew Global Survey shows that $71 \%$ of ordinary citizens consider food safety a significant problem in China (Wike and Parker, 2015). The public has also exerted pressure on government administrations to improve the situation (Spencer, 2008; MacLeod, 2012; Wu et al., 2017). These facts indicate that Chinese citizens negatively perceive the current food safety situation. Food safety problems not only threaten the Chinese people's health, but also have a far-reaching social and

(c) The Author(s), 2022. Published by Cambridge University Press. This is an Open Access article, distributed under the terms of the Creative Commons Attribution licence (http://creativecommons.org/licenses/by/4.0/), which permits unrestricted re-use, distribution and reproduction, provided the original article is properly cited. 
political impact. Differing from an analysis of the relationship between food safety problems and state's formal institutions and laws, this study explores the politics of food safety problems from the viewpoint of political psychology. Ordinary Chinese people's perceptions of food safety problems and their attitudes toward the governments are at the center of the analysis.

In China, the politics of food safety problems involve three dimensions: the differentiated public awareness of food safety problems based on socioeconomic status; the political impact of food safety problems on the public's trust in the government; and ordinary people's attribution of governmental responsibility regarding food safety. First, the marketization and individualization of the Chinese society generates an unequal vulnerability of risks among people of different socioeconomic statuses. The differentiated awareness of the severities of food safety problems is rooted in the unequal distribution of economic sources and cognitive capabilities among the Chinese public during modernization. Second, the multilevel government system separates the responsibility of the food safety supervision between the central and local governments. Thus, do the food safety problems erode the public's trust in local governments more than in the central government? This study examines the impact that citizens' concerns about food safety have on the public's trust in the government across different levels. Third, even though both the central and local governments have supervisory duties with respect to food safety, it is unclear how the public perceives the responsibility of the governments, and how they attribute the major responsibility to them. Is it the central government or the local government that will be under fire if food safety problems occur? These questions involve how these problems affect the ordinary Chinese people's attitudes toward political authorities, which constitutes the core of the politics that concern the food safety problems in China. The rising public awareness of food safety problems may redefine the Chinese people's beliefs and activities within the political field. For this reason, these problems transcend the scope of public health and are related to politics.

\section{Food safety problems and risk society}

Food safety problems have undergone different stages in China and the concept of 'food safety' has multiple meanings. Yan (2012) divides food safety problems into three levels of food hygiene, unsafe food, and poisonous food. In the 1950s, food contamination and poisoning had been the most serious issues. The health centers, the sanitation reporting system, and the petition system have been gradually established. Besides, hygiene awareness is growing among food producers and consumers. With an increase in sanitation knowledge, traditional food poisoning cases such as spoiled foods and improper food preparation declined. However, the cases of food poisoning as caused by toxic additives and harmful chemicals have risen since the 1980s (Yan, 2012; Klein, 2013). This change indicates that the major food safety problems have shifted from food hygiene to 'unsafe food' and 'poisonous food' in accordance with Yan's categorizations. New risks associated with chemicals, pesticides, food additives, and food adulteration rapidly increased and became the major types of food safety problems. The notorious 2008 Sanlu melamine-tainted milk scandal further strengthened the public's concerns regarding food safety problems.

The prevalence of food safety problems and widespread public concerns indicates the arrival of a risk society in China (Yan, 2012). Food safety risks include the conventional risks of food hygiene and the new risks of toxic food (Buchler et al., 2010). The risk society theory states that ordinary people suffer from the unintended consequences of 'manufactured' risks (techno-scientifically produced risks) that are largely derived from industrial modernization. The myth of science and technology creates an illusion of controlling and avoiding the risks. However, industrial modernization ironically causes uninsurable and unaffordable risks (Beck, 1992). The new food safety risks associated with pesticides and toxic chemicals exist throughout the whole process of food production, processing, and distribution.

China's modernization is time-compressed, and the current society features both industrial and postindustrial characteristics (Thiers, 2003; Yan, 2012). Within the Chinese context, food safety problems incorporate food poisoning and toxic food. Food poisoning is not only associated with hygiene issues that can be diminished by using scientific knowledge at the industrial society stage, but also 
relates to toxic food that contains pesticides and harmful chemicals (Yan, 2012). The latter is the ironical result of the risks in the technological advances of the post-industrial society. Two other types of food safety problems in Yan's categorization (unsafe food and poisonous food) relate to the manufactured risks from modern agricultural technologies, regardless of whether it is motivated by the deliberate contamination of food. Therefore, food safety risks in China include the conventional risks of food hygiene, and the manufactured risks of toxic food.

Risk society in the post-industrial stage stresses the equalizing effects of risks, and the risks are universal. Manufactured risks strike everyone as being on an egalitarian basis (Beck, 1992: 36-39). However, food safety risks are unequally distributed across Chinese society (Yan, 2012), and the vulnerability to the risks varies among people of different socioeconomic statuses in China. Since 1985, the economic gap in the Chinese population has widened, and the measurement of income distribution (the Gini coefficient) has reached very high levels (Li et al., 2013; Xie and Zhou, 2014). The economic disparities within the Chinese population further intensify the unequal distribution of risks; the unequal distribution of wealth coincides with the unequal distribution of risks, which causes an increase in social injustice (Yan, 2012). This is the Chinese model of risk society.

Food safety risks are unequally distributed, and people of different socioeconomic statuses are distinctively vulnerable to these risks. The unequal distribution of food safety risks is associated with the politics of food safety problems in China. China's modernization proceeds with the widening of the gap in the economic, social, and political rights between people from different areas and regions. People of high socioeconomic status have more financial and cognitive abilities to protect them from risks, while people of low socioeconomic status are more vulnerable to health hazards. Ethnographic fieldwork concerning Chinese people's everyday food shopping found that food safety risks produced diversified and differentiated responses. People of higher socioeconomic status paid much attention to food selection and developed various methods to identify problematic food (Wang et al., 2008; Klein, 2013; Si et al., 2018). Indeed, people of higher socioeconomic status can pay a high price for safe food, while people of lower socioeconomic status must take a price-priority strategy regarding food. There are different strategies for coping with food safety problems among people of different socioeconomic statuses. In addition, the difference lies in the gap in the awareness of food safety problems. The latter is a prerequisite for taking protective measures. People of different socioeconomic statuses distinctively perceive and respond to food safety risks. In the context of Chinese society, we will empirically examine the disparities in the perceptions of food safety problems among people of different socioeconomic statuses. This is the outcome of the Chinese model of risk society.

Education and income are two primary indicators that measure socioeconomic status. However, the empirical findings of the effects of education and income on the perceptions of food safety problems are not consistent (Wang et al., 2008; Buchler et al., 2010; Liu and Ma, 2016; Wu et al., 2017). Even though the positive relationship between education and income is widely presumed, education is not always highly rewarded. In China, the rich are not equivalent to the educated. The existing empirical studies demonstrate that the return to education in Chinese society varies significantly across generations, gender, region, and periods of time (Wu and Xie, 2003; Fleisher and Wang, 2005; Ren and Miller, 2012). In particular, China's higher education expansion increases the unemployment rate among college graduates who have a high level of education without a high level of income (Li et al., 2014). Therefore, we used these two indicators of socioeconomic status separately to investigate how the perception of food safety problems varies across the different levels of education and income.

Based on the above elaboration, we propose the following hypotheses regarding public awareness of food safety problems.

Hypothesis 1.1: People with high education levels tend to have a high level of concern regarding food safety problems.

Hypothesis 1.2: People with a high income tend to have a high level of concern regarding food safety problems. 


\section{Public concerns for food safety and political trust}

The politics of food safety problems means that food safety is not confined to the field of public health and affects the public's trust in the government. The public's trust in the government is of fundamental importance to the effectiveness of governmental performance and the stability of political systems (Tolbert and Mossberger, 2006; Yang and Holzer, 2006; Cooper et al., 2008). Citizens expect the government to perform well in areas related to their daily lives. When administrative performance falls below their expectations, they will lose their trust in the government. Accordingly, citizens may become distrustful of the government because of its failures in the supervision and regulation of food safety. As some government officials are involved in food safety scandals, the corruption in regulatory agencies arguably fosters public discontent further (Tam and Yang, 2005; Yan, 2012; Yang, 2013). Citizens tend to view food safety problems as a failure of administrative supervision and as indicative of fundamental problems rooted in the regime (Lei and Zhou, 2015).

The multilevel government system ensures that the central and local governments have separate responsibilities in the regulation of the food industry (Lin, 2016; Wu et al., 2017). The central government plays a leadership role in food safety regulations. It enacts food safety laws and makes rules for regulating the industry. The local government undertakes specific implementation of supervision, including overseeing the quality of food and imposing punitive penalties on violators. Researchers use the term 'fragmented authoritarianism' to outline the political and social characteristics of China's authoritarian system (Lieberthal and Oksenberg, 1988; Martha, 2009; Brødsgaard, 2016). Authoritarian central power combines with divided administrative powers, and various implementation agencies have parochial organizational and political goals that are not necessarily consistent with those of the central authority. This double-layered administrative structure affects supervision and policy implementation about food safety. Food safety problems may have negative effects on the public's trust, even though the impact may vary across the central and local levels of the government.

The Chinese government is fully aware of the potential threats that food safety problems impose on its ruling. To study the effects of food safety problems on the public's trust in the government, we must take the government's agency into consideration. Clearly, the government attempts to avoid blame from the masses for food safety problems, and constructs a discourse on the responsibility of food safety. Rhetorically, this responsibility is distributed among the state, the food industries, and consumers (Klein, 2013: 378). However, the government manipulates the major subject responsible for food safety risks in a sophisticated manner. In order to minimize the negative effects of food safety problems on political trust, the Chinese government adopts two strategies.

First, the government pushes the individual to cope with risks and stresses the consumer's own responsibility. Marketization and individualization force ordinary people to take responsibility for food safety risks. In a risk society, individualization creates a state of 'disembedding,' in which the people are disembedded from the collective institutions and traditional support networks. They become the center for action, and must individually cope with everyday life risks. This process compels a compulsive self-determination for individuals who must be responsible for all of their problems themselves (Giddens, 1991; Beck, 1992; Bauman, 2000; Beck and Beck-Gernsheim, 2002). The Chinese society has also undergone individualization, and the party-state manages the process of individualization for maintaining authoritarian rule (Yan, 2009; Klein, 2013; Tilt, 2013). As a result, the Chinese model of individualization features an absence of cultural democracy and a welfare state (Yan, 2009). Chinese people are too fragile in the face of an authoritarian state, and the government shifts the responsibility to ordinary people and holds individuals responsible for food safety risks. In particular, the asymmetric information on food production, distribution, and sales increases the vulnerability of consumers in the face of food safety risks, while the control of the quality and safety of food is in the hands of the producers and government agencies (Pawsey, 2000). The government covertly shirks its responsibility by making ordinary people face food safety risks in the wake of the individualization of society. Chinese people must involuntarily accept the state-imposed new personal responsibility and develop various methods to select and shop for safe food (Klein, 2013; Si et al., 2018). 
Second, when scandals are uncovered, the government attributes all responsibility to the immoral and greedy individuals involved in the food's production, processing, and transportation in a selfserving manner. The government publicly promotes its efforts in the supervision and regulation of food safety problems and performs as an arbitrator in food safety incidents. When these incidents occur, the government overtly criticizes the unscrupulous food producers and processors, and immediately announces measures to inspect the relevant companies and people. The government never mentions its own regulatory failures, and describes corrupt officials as partially responsible in particular cases to avoid endangering its own authority. In rhetoric, the Chinese government labels itself as a representative of the people's interests, and a protector of the masses. For this reason, the government allows certain types of food safety incidents to be reported; small, locally focused issues that are not linked to broader social instabilities are often tolerated. Any media coverage of food safety problems is under contestation between a combined state and corporate hegemony and the citizen-consumers' counter-hegemony (Yang, 2013). Through information control and sophisticated framing, the government constructs the image of a protector, and by punishing the companies and people involved, it seeks to quench the public's fury and create a shield for itself.

Do these tactics take effect? While the masses express their discontentment regarding the food safety supervision agencies (Yan, 2012; Klein, 2013), the distrust in the specific regulatory agencies is not equivalent to the distrust in the government as a whole. Particularly, the central government manipulates information to obtain the public's trust. Previous studies found that in China, the central government enjoys higher levels of public trust than local governments, and such hierarchical trust is the outcome of political control (Li, 2004, 2016; Wu and Wilkes, 2018). Case studies and ethnographic fieldwork show that food safety problems cause Chinese residents in particular cities or the countryside to express discontentment with local governments (Yan, 2012; Klein, 2013; Si et al., 2018). Will the Chinese public blame the central government for food safety scandals, or only limit their criticisms to the local levels? We tentatively posit that the central government successfully prevents food safety problems from eroding the public's trust in the central government and that concerns about food safety only erode political trust at the local level.

Hypothesis 2: Public concerns about food safety undermine trust in local governments.

Hypothesis 3: Public concerns about food safety do not undermine trust in the central government.

\section{Perception and attribution of governmental responsibility}

Even though food safety problems involve multiple stakeholders, the government oversees food regulations and administrative work and cannot be exempted from the responsibility of ensuring safety within the food industry (Nucci et al., 2009; Wu et al., 2017). The public's concerns about food safety problems are rising because this matter is closely related to the public's quality of life. As a result, food safety problems will cause public demands for addressing this prominent issue and impose pressure on the government's administration (Spencer, 2008; MacLeod, 2012).

The multilevel governmental system separates the duties of supervising food safety between the central and local governments (Si et al., 2018). China's food safety problems indicate a paradox in central-local relations regarding regulatory regimes, and a unitary regulatory structure has difficulties in its effective control of food safety problems within a complex multilevel context (Yasuda, 2015). Due to challenges from this unitary regulatory system, the central and local governments must coordinate their regulations of food safety problems. Hence, the way citizens perceive and attribute governmental responsibility requires further study. Is it the central or local government that is viewed as having the major responsibility for supervising food safety? Attribution of responsibility matters because it reflects which level of government will be under fire when there is a food safety problem. Studying citizens' attributions of responsibility will advance our knowledge of the politics of food safety problems in China. As previously stated, Chinese people trust the central government more than they 
do local governments. The central government also serves as a protector of people and blames local governments and officials when food safety problems occur. Therefore, we posit that Chinese citizens believe that local governments bear most of the responsibility for food safety problems (Figure 1).

Hypothesis 4: Chinese citizens attribute responsibility for food safety problems to the local government.

As food safety risks are unequally distributed in the Chinese model of risk society, previous sections of this article have analyzed how socioeconomic status affects the Chinese people's perception of food safety problems. The negative effects of food safety problems on the public's trust in the government are also contingent on socioeconomic statuses. In light of the critical citizenry theory (Norris, 1999; Kim, 2010), the negative effect of food safety problems on political trust will be more salient in highstatus populations who have higher expectations of governmental performance. They tend to blame the government and lose trust if a food safety situation becomes worse. If such an assumption is reasonable, the government will be under less pressure from the disadvantaged population. Education and cognitive capabilities prevent people of low socioeconomic status from recognizing the severity of food safety problems, and their trust in the government may decrease more slowly than their counterparts of higher socioeconomic statuses. Accordingly, we assume that people's trust in the central and local governments and their attribution of governmental responsibility changes across different socioeconomic statuses. Ordinary people's education and incomes moderate the effect of food safety problems on political trust and the means of attributing the responsibility to the government.

Hypothesis 5.1: There are interaction effects of socioeconomic status and concerns about food safety problems on the public's trust in the central and local governments.

Hypothesis 5.2: There are interaction effects of socioeconomic status and concerns about food safety problems on the attribution of governmental responsibility regarding food safety problems.

\section{Data and methods}

\subsection{Data}

This study will address the politics of food safety problems in China by using the latest national survey data. The Chinese dataset of the fourth round of the Asian Barometer Survey (ABS) was conducted by face-to-face interviews from July 2015 to March 2016. ${ }^{1}$ A representative sampling method of probability proportional to size was applied to randomly select respondents. Residents aged 18 and above in the sampled community were recruited. The response rate was $67.65 \%$. The survey data are the latest nationwide probes into the Chinese public's perception of food safety problems, and offer empirical materials to examine the politics of food safety problems in China.

\subsection{Measures}

The variable of public concerns about the food safety problem was measured by the following question: 'What score would you use to evaluate the current situation of food safety in China on a scale from 0 (very good) to 10 (very bad)?'2 The higher scores indicate that a person has high levels of concern about the food safety situation in China. Attribution of the government's responsibility was

\footnotetext{
${ }^{1}$ Data analyzed in this article were collected by the Asian Barometer Project (2013-2016), which was co-directed by Professors Fu Hu and Yun-han Chu and received major funding support from Taiwan's Ministry of Education, Academia Sinica and National Taiwan University. The Asian Barometer Project Office (www.asianbarometer.org) is solely responsible for the data distribution. The authors appreciate the assistance in providing data by the institutes and individuals aforementioned. The views expressed herein are the authors own.

${ }^{2}$ Public concern about food safety was the country-specific items that were designed by the Chinese survey team.
} 


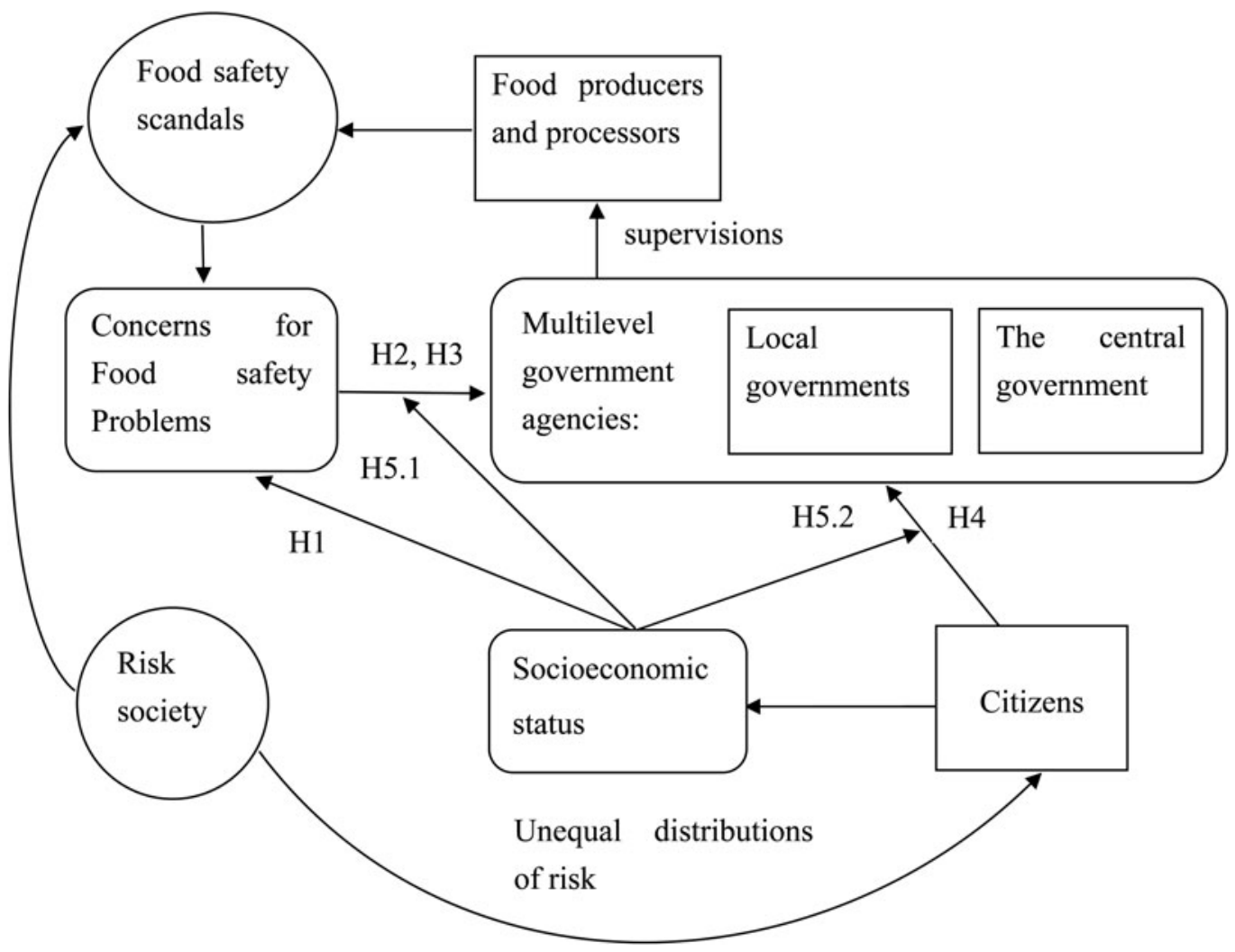

Figure 1. Main actors in the argument and related hypotheses.

measured by asking respondents which level of government should take major responsibility for food safety problems. The response of attributing responsibility to central government was coded as 1 , and attributing responsibility to local government as 0 . Therefore, attribution of government responsibility was a dummy variable.

Trust in government was measured at the central and local levels. Following previous studies (Tolbert and Mossberger, 2006; Yang and Holzer, 2006), trust in government was measured by asking respondents to indicate the extent of their trust in central and local governments on a six-point scale from 1 (strongly distrust) to 6 (strongly trust). Based on Easton's (1965) classic divisions about diffuse and specific trust, trust in governments is specific political trust.

The demographic variables (age, gender, and education) were controlled for in regression analyses. Age was measured on a scale from 1 (18-29 years) to 5 (over 60 years). Gender was measured as either 0 (male) or 1 (female). Education level was measured from 1 (primary school) to 4 (college and above). We estimated the effects of economic status on public concerns about food safety problems by using ordinary least squares (OLS) regression. The effects of public concerns about food safety on trust in central and local governments were also estimated by OLS. As attribution of responsibility to central or local government was coded on a binary scale, a logistic regression model is an appropriate method.

\section{Results}

\subsection{Public awareness of food safety problems based on socioeconomic status}

Table 1 presents the results regarding the relationships between socioeconomic status and the public's concerns about food safety problems. The two indicators of socioeconomic status were significantly related with the perception of food safety problems. Compared with the citizens who had received 
a primary school education, those who had a higher level of education were more likely to perceive food safety problems. People with higher levels of income tended to be more concerned about food safety problems than their low-income counterparts. The results confirm the unequal distribution of the vulnerability of the food safety risks. Even though food safety problems threaten everyone's health, the disadvantaged are less conscious of the dangers to take proper precautions, and such cognitive defects cause the disadvantaged to suffer from higher food safety risks. The unequal distribution of risks means that people have different strategies to cope with food safety problems, and there is a gap in the perception of the problems due to unequal socioeconomic statuses. Therefore, the politics of food safety problems in China manifests itself as the unequal distribution of the vulnerability of food safety risks among people of different socioeconomic statuses, which is the result of enlarging the inequalities in the wake of the state-managed modernization.

\subsubsection{The political impact of food safety problems on the public's trust in the government}

We explored the effects of the public's concerns of food safety on the trust in the government. Tables 2 and 3 show the results. Governmental performance in food safety supervision involves government bureaucracies at different levels. We examined the respective effects of public concerns about food safety on trust in the central and local governments. Models 2 and 5 show that the public's concerns for food safety were negatively related with trust in the central and local governments $(\beta=-0.07$, $p<0.001 ; \beta=-0.11, p<0.001)$. Worse food safety situation weakens the public's trust in the government, whether it is the central or local government. The negative relationship between the perception of food safety and political trust indicates that the government's attempt to shift the responsibility is not successful. Even though the individualization of the Chinese society forces ordinary people to take responsibility for any risks in their daily lives, the masses believe that the government cannot be exempt from the responsibility of food safety problems. In addition, the central government enforces tactics to make local governments a scapegoat for the failure of food safety supervision. However, the central government's efforts seem ineffective. Food safety problems worsen the public's trust in both the central and local governments, and the central government is not exempt from losing the public's trust in regard to food safety problems. The worsening trust in the government is the political response that the Chinese public has had to food safety problems.

Moreover, we are interested in whether the Chinese model of risk society intervenes in the ways in which food safety problems affect the public's trust in the government. As previously stated, people of different socioeconomic statuses distinctively confront food safety risks. In such situations, the political impact of food safety problems on the public's trust in the government may vary among people of different socioeconomic statuses. Even though food safety problems cause a decline in public trust, the degree of the decline may change as people perceive the risks differently.

We empirically examined the above assumption by introducing interaction items for the socioeconomic status and perception of food safety problems. Tables 2 and 3 report the results. Models 3 and 4 tested how the negative effect of food safety problems on the public's trust in the central government varies in populations of different socioeconomic statuses. First, we examined the interaction effects of education and concerns for food safety on the public's trust in the government. Model 3 shows that the interaction effect on trust in the central government was significant $(\beta=-0.08$, $p<0.001)$. The results indicate that the negative effects of concerns for food safety on the public's trust in the central government were the most striking among those with a high level of education. Highly educated people lose trust in the central government more drastically when food safety problems become worse. Next, model 4 examined the interaction effect of income and concerns for food safety on the public's trust in the central government. The interaction effect was not significant $(\beta=-0.02, p>0.1)$, which indicates that the negative effect of concerns for food safety on trust in the central government did not change with variations in income groups. Concerns regarding food safety undermine the wealthy people's trust in the central government as it does for poor people, and the wealthy people did not show a significant difference from the poor people in terms of losing trust in the central government. 
Table 1. Socioeconomic status and concerns for food safety

\begin{tabular}{lr}
\hline Dependent variable: concerns for food safety & $(1)$ \\
\hline Age (reference: age 18-29) & $0.12(0.18)$ \\
$\quad$ Age 30-39 & $0.13(0.18)$ \\
Age 40-49 & $-0.49(0.18)^{\star \star}$ \\
Age 50-59 & $-0.48(0.18)^{\star \star}$ \\
Age 60+ & $0.24(0.10)^{\star}$ \\
Gender & $0.56(0.13)^{\star \star \star}$ \\
Education (reference: primary school) & $1.27(0.17)^{\star \star \star}$ \\
$\quad$ Middle school & $1.62(0.19)^{\star \star \star}$ \\
$\quad$ High school & $0.04(0.01)^{\star}$ \\
College & $4.46(0.25)^{\star \star \star}$ \\
Income & 0.10 \\
Intercept & 0.09 \\
Adjusted $R^{2}$ & 2139 \\
$N$ & \\
\hline
\end{tabular}

Note: Standard errors in parentheses.

${ }^{\star} P<0.05,{ }^{\star \star} P<0.01,{ }^{\star \star \star} P<0.001$, two-tailed test.

Models 6 and 7 examine how the socioeconomic status conditions the negative effects of food safety problems on the public's trust in local governments. The results concerning the effects in local governments were similar to the previous findings regarding the central government. The moderation effect for education was significant $(\beta=-0.08, p<0.001)$, while that of income was not $(\beta=-0.01$, $p>0.1$ ). When food safety problems become worse, people with a high level of education tended to considerably distrust the local governments (model 6), yet the wealthy did not lose more trust in local governments than their poor counterparts (model 7).

In the context of the individualization of Chinese society, the politics of food safety problems manifests itself in the unequal distribution of the vulnerability of risks and the differentiated impacts on political trust. The above empirical findings demonstrate that the negative effects of food safety problems on the public's trust in the government vary across populations of different socioeconomic statuses. With an increase in the perceptions of the severity of food safety problems, the public's trust in the government declines drastically among those with a high level of education, while there is a slow downward trend among the less educated. Even though ideological control persists in China's school system, education expands people's cognitive capabilities and empowers them to critically understand their lives. Our study shows that people with higher education do not blindly trust the government in terms of food safety problems, and their trust drastically decreases when they are aware of severe food safety situations. In contrast, the low-educated people hardly realize the food safety problems around them, and are less inclined to withdraw trust in the government as a result of them. They may blame the food producers and processors for the problems. Such tendencies prevent the disadvantaged from taking collective action to impose pressure on the government.

\subsubsection{Attribution of governmental responsibility regarding food safety}

We examine how the public attributes responsibility to government (see Table 4). Model 8 shows that public concerns for food safety were positively related with attribution of responsibility to the central government $(\beta=0.06, p<0.01)$. Even though food safety problems indiscriminately erode the public's trust in both the central and local governments, Chinese citizens tend to attribute the major responsibility to the central government when they are more concerned about food safety problems.

The Chinese citizens' attribution of responsibility to the central government indicates the political impact of food safety problems. People who are more concerned about food safety problems tend to believe that the central government should take the major administrative responsibility for an unsatisfactory situation. This reflects the fact that the public blames the central government more than local 
Table 2. Multivariate analysis of the effects of food safety concerns on trust in the central government

\begin{tabular}{|c|c|c|c|}
\hline \multicolumn{4}{|c|}{ Dependent variable: trust in the central government } \\
\hline & $(2)$ & (3) & (4) \\
\hline \multicolumn{4}{|l|}{ Age (reference: age 18-29) } \\
\hline Age $30-39$ & $0.11(0.07)$ & $0.13(0.07)$ & $0.12(0.07)$ \\
\hline Age $40-49$ & $0.22(0.06)^{\star \star}$ & $0.22(0.06)^{\star \star \star}$ & $0.22(0.06)^{\star \star}$ \\
\hline Age $50-59$ & $0.35(0.07)^{\star \star \star}$ & $0.35(0.07)^{\star \star \star}$ & $0.35(0.07)^{\star \star \star}$ \\
\hline Age $60+$ & $0.48(0.06)^{\star \star \star}$ & $0.49(0.06)^{\star \star \star}$ & $0.49(0.06)^{\star \star \star}$ \\
\hline Gender & $-0.14(0.04)^{\star \star \star}$ & $-0.14(0.04)^{\star \star \star}$ & $-0.14(0.04)^{\star \star \star}$ \\
\hline \multicolumn{4}{|l|}{ Education (reference: primary school) } \\
\hline Middle school & $0.01(0.05)$ & $-0.02(0.05)$ & $0.00(0.05)$ \\
\hline High school & $0.04(0.06)$ & $0.03(0.06)$ & $0.04(0.06)$ \\
\hline College & $-0.12(0.07)$ & $-0.09(0.07)$ & $-0.12(0.07)$ \\
\hline Income & $0.00(0.01)$ & $0.00(0.01)$ & $0.00(0.01)$ \\
\hline Concerns for food safety & $-0.07(0.01)^{\star \star \star}$ & $-0.07(0.01)^{\star \star \star}$ & $-0.07(0.01)^{\star \star \star}$ \\
\hline Education $\times$ concerns for food safety & & $-0.08(0.02)^{\star \star \star}$ & \\
\hline Income $\times$ concerns for food safety & & & $-0.02(0.02)$ \\
\hline Intercept & $5.49(0.10)^{\star \star \star}$ & $5.48(0.10)^{\star \star \star}$ & $5.48(0.10)^{\star \star *}$ \\
\hline$R^{2}$ & 0.11 & 0.12 & 0.11 \\
\hline Adjusted $R^{2}$ & 0.10 & 0.11 & 0.10 \\
\hline$N$ & 2003 & 2003 & 2003 \\
\hline
\end{tabular}

Note: Standard errors in parentheses.

${ }^{\star \star} P<0.01,{ }^{\star \star \star} P<0.001$, two-tailed test.

Table 3. Multivariate analysis of the effects of food safety concerns on trust in local governments

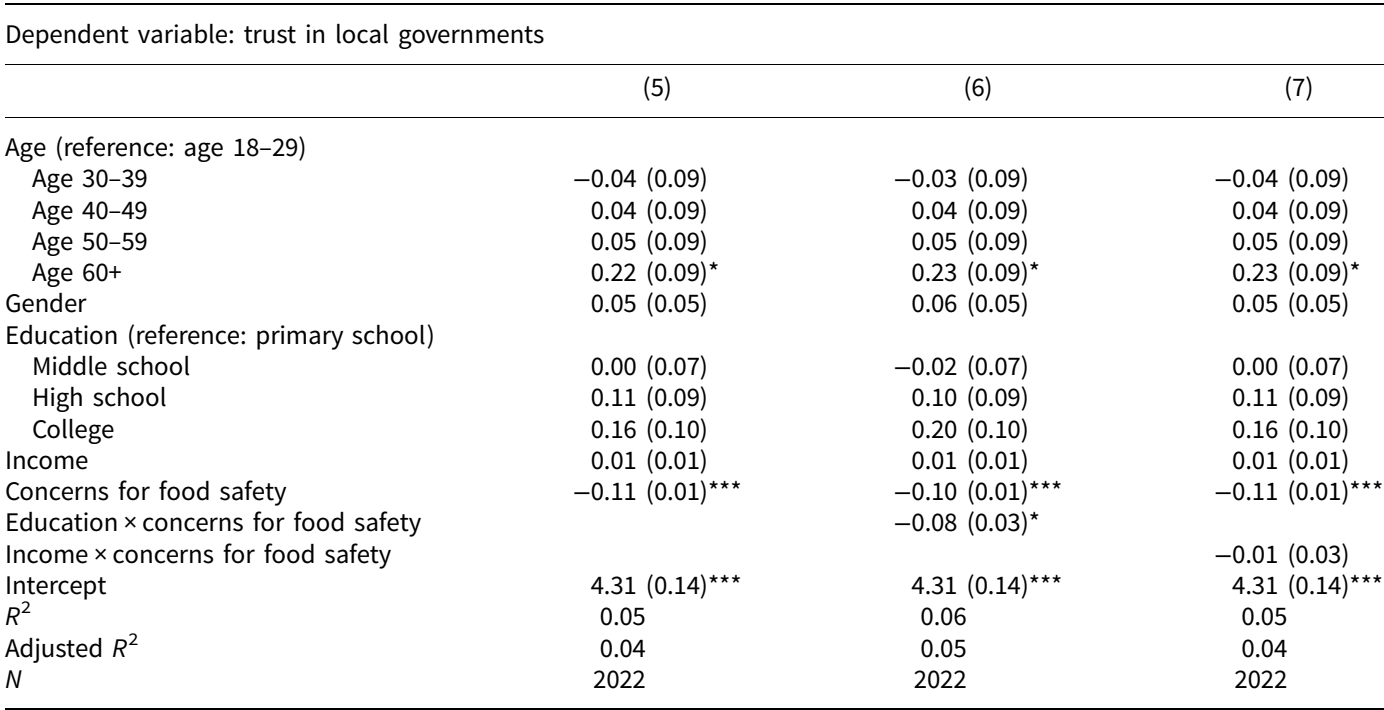

Note: Standard errors in parentheses.

${ }^{\star} P<0.05,{ }^{\star * *} P<0.001$, two-tailed test.

governments for food safety problems, even though it is the local government that, in practice, primarily exercises administrative supervision over food safety. The theory of hierarchical trust predicts that the public attributes responsibility for poor performance to the local government and blames it, while the central government is exempt from this responsibility and enjoys higher public trust ( $\mathrm{Li}, 2016$; Liu and Raine, 2016). Our empirical evidence shows that when citizens are concerned about food safety problems, they attribute the major responsibility to the central government rather than the local government. The public, and particularly the younger generation, does not transfer perceptions of failure 
Table 4. Logit analysis of attributing food safety issues to governments

\begin{tabular}{|c|c|c|c|}
\hline & $(8)$ & (9) & $(10)$ \\
\hline \multicolumn{4}{|l|}{ Age (reference: age 18-29) } \\
\hline Age $30-39$ & $-0.02(0.17)$ & $-0.02(0.17)$ & $-0.04(0.17)$ \\
\hline Age $40-49$ & $-0.34(0.16)^{\star}$ & $-0.33(0.16)^{\star}$ & $-0.34(0.16)^{\star}$ \\
\hline Age $50-59$ & $-0.33(0.17)$ & $-0.33(0.17)$ & $-0.34(0.17)^{\star}$ \\
\hline Age $60+$ & $-0.29(0.17)$ & $-0.29(0.17)$ & $-0.32(0.17)$ \\
\hline Gender & $0.15(0.10)$ & $0.15(0.10)$ & $0.15(0.10)$ \\
\hline \multicolumn{4}{|l|}{ Education (reference: primary school) } \\
\hline Middle school & $-0.10(0.13)$ & $-0.08(0.13)$ & $-0.06(0.13)$ \\
\hline High school & $-0.08(0.16)$ & $-0.07(0.16)$ & $-0.09(0.16)$ \\
\hline College & $-0.09(0.19)$ & $-0.12(0.19)$ & $-0.13(0.19)$ \\
\hline Income & $-0.02(0.01)$ & $-0.02(0.01)$ & $-0.02(0.01)$ \\
\hline Concerns for food safety & $0.06(0.02)^{\star \star}$ & $0.06(0.02)^{\star \star}$ & $0.06(0.02)^{\star \star}$ \\
\hline Education $\times$ concerns for food safety & & $0.05(0.05)$ & \\
\hline Income $\times$ concerns for food safety & & & $0.16(0.05)^{\star \star}$ \\
\hline Intercept & $-0.49(0.25)$ & $-0.49(0.25)$ & $-0.48(0.25)$ \\
\hline $\operatorname{LR} \chi^{2}$ & 23.38 & 24.28 & 33.23 \\
\hline Pseudo $R^{2}$ & 0.01 & 0.01 & 0.01 \\
\hline$N$ & 1710 & 1710 & 1710 \\
\hline
\end{tabular}

Note: Standard errors in parentheses.

${ }^{\star} P<0.05,{ }^{* \star} P<0.01$, two-tailed test.

in administration over food safety from central to local government. Therefore, the central government becomes the target of the public's discontent, which is most undesirable for the CCP leadership.

To test the effect of socioeconomic status, we examined the interaction effects of the socioeconomic status and the perception of food safety problems. Model 9 tested the effect of education, and the interaction effect was insignificant $(\beta=0.05, p>0.1)$. The results indicate that citizens with a high level of education did not display a different pattern of attribution for governmental responsibility when compared with those who had lower levels of education. Regardless of education, people unanimously attributed the major responsibility to the central government in terms of food safety problems. Model 10 tested the effect of income, and the results show that the interaction effects of income and the perception of food safety problems were significant $(\beta=0.16, p<0.01)$. The perceptions of food safety had the largest effect on attributing the responsibility to the central government among those who had a low income. When food safety problems become severe, people with low incomes are more likely to attribute the responsibility to the central government more than wealthy people, and they believe that the central government should take the majority of the responsibility for food safety problems. Low-income people tend to hold a belief that as long as the central government pays attention to food safety problems, the situation can improve rapidly.

\section{Conclusion}

In globalization, the risk associated with food safety is not confined to one country but is diffused throughout the world (Nucci et al., 2009; Ross, 2012; Marques et al., 2015). Nevertheless, developing countries face more challenges because of unsound legal and administrative systems, and a relative absence of civil society (Soeters and Tessema, 2004; Islam and Mahmud, 2015). Although there has been an expansion of the intermediary sector of non-governmental organizations (NGOs) in China, the CCP employs them to strengthen its rule and ruthlessly disempowers and oppresses NGOs that may threaten state hegemony (Howell, 1995; Tam and Hasmath, 2015; Han, 2018). An absence of independent and vibrant NGOs causes low-income and poorly educated people to be more vulnerable while facing food safety problems. The state-managed modernization in China combines a capitalist economy with authoritarian politics. The past few decades have witnessed marketization, the 
individualization of society, the continuity of the one-party rule, and the arrival of a Chinese model of risk society that is comprised of conventional and post-industrial risks. Expanding economic inequalities have been transforming the egalitarian nature of risk. Hence, socioeconomic status matters in relation to people's circumstances and the risks they face. In this sense, the findings of the present study regarding the relationships between food safety problems, risk society, and political trust in China have general implications for other countries.

Food safety problems not only involve public health, but also have significant political influences. First, the political-economic outcomes of China's modernization are the individualization of society and the unequal distribution of the vulnerability of risks among the public. Food safety risks vary significantly across people of different socioeconomic statuses. Second, the public's negative perceptions of the food safety situation cause immense damage to trust in the government. Our study shows that food safety problems provoke a decline in political trust, and ordinary people become indiscriminately distrustful of both the central and local governments when worrying about food safety problems. This indicates the significance of quality-of-life issues in the public's evaluation of government. Even though the central government has tactics to shift the responsibility to local governments and food producers in an attempt to avoid the public's criticism of itself, the central government is not exempt from losing the public's trust with regard to food safety problems. Third, public concern about food safety problems was positively related with the attribution of responsibility to the central government. It is the central rather than the local government that will be under fire when the public perceives a poor food safety situation.

Upon combining these findings, we can conclude that people with low socioeconomic statuses are situated in an extremely disadvantaged position in the face of food safety problems. Even though there are high risks, the people of low socioeconomic status are unable to realize the severity of the food safety problems; they blame the government for food safety problems less than their high-status counterparts. When low-status people become aware of these problems, their perceptions do not considerably undermine their trust in the government which prevents them from taking collective action to impose pressure on the government. Regarding the attribution of governmental responsibility, the interaction effects for income and the perception of food safety problems were significant, which indicates those with a low income were more inclined to attribute the responsibility for food safety problems to the central government. Placing the majority of the responsibility on the central government is due to low-status people's expectations for it to solve the problems for the sake of the 'people's interests.' They tend to believe that the 'benevolent' central government will secure food safety for the sake of people. The cognitive dissonance theory (Festinger, 1957) may account for the psychological mechanism of the cognition of poor people. Under financial constraints, those with a low income have limited options in dealing with food safety problems, and even have not recognized the severity of the food safety risks threatening their health. They have to believe that the central government has taken responsibility to ensure food safety to prevent anxiety and discomfort. The unequal socioeconomic status and authoritarian political culture constrains and frames their perception of food safety problems and the roles of the government.

As food safety risks are unequally distributed and the individualization of Chinese society reconstructs individual-state relations, we further examined whether the negative effects of food safety problems on the public's trust in the government varied across different socioeconomic-status groups. The results show that the negative effect of concern was most significant in highly educated people. Such patterns were also observed in the interaction effect of the concerns for food safety and education on the public's trust in local governments. Therefore, an increase in education will reinforce this negative effect. Reducing unequal income distribution and improving the education of ordinary people is crucial for them to recognize the risk around them. As long as people are aware of dangers in food safety, they can take measures to reduce risk and create pressure on governments. Moreover, given the negative effects of the individualization of society, citizens should set up non-government organizations and use digital technologies to enhance societal capabilities of supervision and punishment. 
Future research should be undertaken in two directions to further the understanding of the politics of food safety. The first is to examine how citizens' experience with food safety problems affects their diffuse political trust. The present study only tests trust in the central and local governments that is specific political trust. In theory, diffuse trust is distinct from trust in specific political institutions (Easton, 1965). It is valuable to explore the effects of food safety problems on diffuse trust in the regime and the overall political community. In addition, food production and transportation links with places. The distance between food producers and consumers in rural areas is less, whereas urban areas import a wide variety of foodstuffs from other places with high mobility of foodstuffs. Differences between urban and rural areas may affect citizens' perceptions of food safety problems and their attribution of governments' responsibility. Future studies should systematically examine the effects of differences between urban and rural areas. The second direction is to examine whether the politics of food safety problems are applicable to other quality-of-life issues. Replicating and extending the present study's findings to other public concerns about emerging quality-of-life issues will help to better understand the outcomes of the Chinese model of risk society and the individualization of society. It will also help identify new challenges that face governmental administration in China. Only by understanding the public's newly emerging demands and their impacts on trust in the government, can we capture the dynamics of China's politics and its future transformation.

Acknowledgments. The authors wish to thank JJPS editor Professor Kentaro Fukumoto and anonymous referees for their constructive comments on earlier drafts of this article.

Financial support. This study was supported by the National Natural Science Foundation of China (no. 71874109, 71871105, 71632008, and 71974128), Humanities and Social Science Fund of Ministry of Education of China (20YJC630033), and Philosophy and Social Sciences Foundation of Shanghai (2019BGL022).

Conflict of interest. The authors declared no potential conflicts of interest.

\section{References}

Bauman Z (2000) Liquid Modernity. Cambridge: Polity Press.

Beck U (1992) Risk Society: Towards a New Modernity. London: Sage Publications Ltd.

Beck U and Beck-Gernsheim E (2002) Individualization: Individualized Individualism and Its Social and Political Consequences. London: Sage Publications Ltd.

Brødsgaard BE (2016) Chinese Politics as Fragmented Authoritarianism: Earthquakes, Energy and Environment. London: Routledge.

Buchler S, Smith K and Lawrence G (2010) Food risks, old and new: demographic characteristics and perceptions of food additives, regulation and contamination in Australia. Journal of Sociology 46, 353-374.

Cooper C, Knotts G and Brennan K (2008) The importance of trust in government for public administration: the case of zoning. Public Administration Review 68, 459-468.

Easton D (1965) A Systems Analysis of Political Life. New York: Wiley.

Festinger L (1957) A Theory of Cognitive Dissonance. Stanford: Stanford University Press.

Fleisher BM and Wang X (2005) Returns to schooling in China under planning and reform. Journal of Comparative Economics 33, 265-277.

Giddens A (1991) Modernity and Self-Identity: Self and Society in the Late Modern Age. Stanford: Stanford University Press.

Gong Q and Jackson P (2012) Consuming anxiety? Parenting practices in China after the infant formula scandal. Food, Culture and Society 15, 557-578.

Han H (2018) Legal governance of NGOs in China under Xi Jinping: reinforcing divide and rule. Asian Journal of Political Science 26, 390-409.

Howell J (1995) Prospects for NGOs in China. Development in Practice 5, 5-15.

Inglehart R (1990) Culture Shift in Advanced Industrial Society. Princeton: Princeton University Press.

Inglehart R and Welzel C (2010) Changing mass priorities: the link between modernization and democracy. Perspectives on Politics 8, 551-567.

Islam MS and Mahmud R (2015) Trust in governance in Bangladesh: ideas, issues and solutions. Millennial Asia 6, $128-146$.

Kim S (2010) Public trust in government in Japan and South Korea: does the rise of critical citizens matter? Public Administration Review 70, 801-810.

Klein JA (2013) Everyday approaches to food safety in Kunming. China Quarterly 214, 376-393.

Laliberté A and Lanteigne M (2008) The Chinese Party-State in the 21st Century: Adaptation and the Reinvention of Legitimacy. London: Routledge. 
Lei Y-W and Zhou DX (2015) Contesting legality in authoritarian contexts: food safety, rule of law and China's networked public sphere. Law and Society Review 49, 557-593.

Li L (2004) Political trust in rural China. Modern China 30, 228-258.

Li L (2016) Reassessing trust in the central government: evidence from five national surveys. China Quarterly 225, $100-121$.

Li S, Sato H and Sicular T (2013) Rising Inequality in China: Challenges to a Harmonious Society. New York: Cambridge University Press.

Li S, Whalley J and Xing C (2014) China's higher education expansion and unemployment of college graduates. China Economic Review 30, 567-582.

Lieberthal K and Oksenberg M (1988) Policy Making in China: Leaders, Structures, and Processes. Princeton: Princeton University Press.

Lin F (2016) What China's food safety challenges mean for consumers, regulators, and the global economy. Brookings. Available at https:/www.brookings.edu/blog/order-from-chaos/2016/04/21/what-chinas-food-safety-challenges-meanfor-consumers-regulators-and-the-global-economy.

Liu P and Ma L (2016) Food scandals, media exposure, and citizens' safety concerns: a multilevel analysis across Chinese cities. Food Policy 63, 102-111.

Liu H and Raine JW (2016) Why is there less public trust in local government than in central government in China? International Journal of Public Administration 39, 258-269.

MacLeod C (2012) Chinese despair at endless food-safety scares. USA Today News. Retrieved from http://usatoday30.usatoday.com/news/world/story/2012-05-28/china-food-safety/55252482/1.

Marques MD, Critchley CR and Walshe J (2015) Attitudes to genetically modified food over time: how trust in organizations and the media cycle predict support. Public Understanding of Science 24, 601-618.

Martha A (2009) 'Fragmented authoritarianism 2.0': political pluralization in the Chinese policy process. China Quarterly 200, 995-1012.

Nathan AJ (2003) China's changing of the guard: authoritarian resilience. Journal of Democracy 14, 6-17.

Norris P (1999) Introduction: the growth of critical citizens? In Norris P (ed.), Critical Citizens: Global Support for Democratic Government. Oxford: Oxford University Press, pp. 1-28.

Nucci ML, Cuite CL and Hallman WK (2009) When good food goes bad television network news and the spinach recall of 2006. Science Communication 31, 238-265.

Pawsey RK (2000) Food and its safety. Medicine, Conflict and Survival 16, 192-200.

Ren W and Miller PW (2012) Changes over time in the return to education in urban China: conventional and ORU estimates. China Economic Review 23, 154-169.

Rigg J (2007) An Everyday Geography of the Global South. London and New York: Routledge.

Ross K (2012) Faking it: food quality in China. International Journal of Asia-Pacific Studies 8, 33-54.

Si Z, Regnier-Davies J and Scott S (2018) Food safety in urban China: perceptions and coping strategies of residents in Nanjing. China Information 32, 377-399.

Soeters JL and Tessema MT (2004) Public management in developing countries: some notes on Eritrea. International Review of Administrative Sciences 70, 623-635.

Spencer R (2008) Chinese authorities covered up baby milk scandal because of Olympics. The Telegraph, Available at https:// www.telegraph.co.uk/news/worldnews/asia/china/2961262/Chinese-authorities-covered-up-baby-milk-scandal-becauseof-Olympics.html.

Tam J and Hasmath R (2015) Navigating uncertainty: the survival strategies of religious NGOs in China. Journal of Civil Society 11, 283-299.

Tam W and Yang D (2005) Food safety and the development of regulatory institutions in China. Asian Perspective 29, 5-36.

Tang W (2018) The 'surprise' of authoritarian resilience in China. American Affairs 20, 101-117.

Thiers P (2003) Risk society comes to China: SARS, transparency and public accountability. Asian Perspective 27, $241-251$.

Tilt B (2013) Industrial pollution and environmental health in rural China: risk, uncertainty and individualization. The China Quarterly 214, 283-301.

Tolbert C and Mossberger K (2006) The effect of E-government on trust and confidence in government. Public Administration Review 66, 354-369.

Wang Z, Mao Y and Gale F (2008) Chinese consumer demand for food safety attributes in milk products. Food Policy 33, 27-36.

Wike R and Parker B (2015) Corruption, pollution, inequality are top concerns in China. Pew Research Center. Available at http://www.pewglobal.org/files/2015/09/Pew-Research-Center-China-Report-FINAL-September-24-2015.pdf.

Wu C and Wilkes R (2018) Local-national political trust patterns: why China is an exception. International Political Science Review 39, 436-454.

Wu X and Xie Y (2003) Does the market pay off? Earnings returns to education in urban China. American Sociological Review 68, 425-442.

Wu X, Yang DL and Chen L (2017) The politics of quality-of-life issues: food safety and political trust in China. Journal of Contemporary China 26, 601-615. 
Xie Y and Zhou X (2014) Income inequality in today's China. PNAS 111, 6928-6933.

Yan Y (2009) The Individualization of Chinese Society. Oxford and New York: Berg Publishers.

Yan Y (2012) Food safety and social risk in contemporary China. Journal of Asian Studies 71, 705-729.

Yang G (2013) Contesting food safety in the Chinese media: between hegemony and counter-hegemony. The China Quarterly 214, 337-355.

Yang K and Holzer M (2006) The performance-trust link: implications for performance measurement. Public Administration Review 66, 114-126.

Yasuda JK (2015) Why food safety fails in China: the politics of scale. The China Quarterly 223, 745-769.

Guanghua Han is an Associate Professor in the School of International and Public Affairs at Shanghai Jiao Tong University. His research focuses on food safety governance and performance in public service organizations.

Yida Zhai is an Associate Professor in the School of International and Public Affairs at Shanghai Jiao Tong University. He studies political psychology, public opinion, and East Asian comparative politics.

Cite this article: Han G, Zhai Y (2022). Risk society and the politics of food safety problems in China. Japanese Journal of Political Science 23, 73-87. https://doi.org/10.1017/S1468109921000372 